\title{
Faksimile skvostného rukopisu Simeona Polockého
}

\author{
Zdeňka Matyušová (České Budějovice)
}

Полоцкий, Симеон: Орел российский. Изд. подг. Л. И. Сазоновой. ИМЛИ им. А. М. Горького. Библиотека Российской академии наук. Москва, 2015. 376 стр., ил. ISBN 978-5- 91674-352-4.

Obsažná publikace v nevídaně nádherném provedení a s krásnou vazbou o rozsahu 376 stran s názvem «Симеон Полочкий: Орел российский» představuje faksimilní reprodukci skvostného rukopisu heraldicko-emblematické poemy Simeona Polockého z roku 1667. Tento literární skvost byl nalezen ve sbírce rukopisných knih Petra I. Velikého v Knihovně Ruské akademie věd. Rusky psaná kniha byla vydána za podpory Ruského humanitárního vědeckého fondu projekt № 15-04-16042.

Rukopis, který v sobě spojuje umění slova a vyobrazení, byl vytvořen a osobně předán autorem carovi Alexeji Michajloviči při př́ležitosti oficiálního jmenování careviče Alexeje Alexejeviče následníkem trůnu.

Nově vydaná kniha obsahuje poprvé zveřejněnou faksimilní reprodukci slavnostního a honosného rukopisu díla, transliterovaný text, záznamy tvůrčích výzkumů při hledání a stanovení vzniku poemy, analýzu jejího obsahu, kompozice a poetiky, komentovaný slovník (slovník-komentář), archeografický popis dochovaných rukopisů díla a ilustrace. Nedílnou součástí knihy jsou dokumentární a obrazové přílohy, které zahrnují texty vztahující se k carským dvorním slavnostním ceremoniím.

Reprezentativní publikace je rozčleněna na sedm hlavních kapitol, následuje pět dokumentárních prríloh, seznam ilustrací, bibliografie, jmenný rejstř́ik a seznam zkratek. Kniha je rovněž opatřena krátkým ruským a anglickým resumé.

«Раннее Новое время в России - заканчивалась одна эпоха и начиналась другая, на смену Средневековъю приходило Новое время. Общество переживало переходную эпоху становления новой российской государственности, превращения
Московского иарства в Российскую империю. Явственно проступили признаки формирующейся новой культурной атмосферы. В офичиальной идеологии и культуре нашли отражение иенностные представления эпохи начионального подбема. Носителем новых культурных и эстетических иниииатив являлся Симеон Полочкий - чентральная фигура русской литературы раннего Нового времени.» ${ }^{1}$

Jak logicky vyplývá z výše uvedeného, stěžejní částí představované publikace je první kapitola, pojmenovaná «Симеон Полочкий - Орел российский - факсимильное воспроизведение подносной рукописи» (Simeon Polockij - Orel ruský - faksimilní reprodukce darovaného rukopisu, s. 9-129). "Факсимильное издание отвечает не только художественно-эстетическим требованиям, но и задачам лингвистического изучения памлтника XVII в., поскольку передает текст в том виде, как он представлен в подносной рукописи, со всеми надстрочными знаками и уда рениями.»²

Druhá kapitola, s označením "Под сенъю двуглавого орла» (Ve stínu-pod křídly dvouhlavého orla, s. 129-194), pojednává o tom, že poprvé $\mathrm{v}$ dějinách ruské poezie se zdrojem tvưrčí inspirace stal státní erb Ruska - heraldický dvouhlavý orel, kterého právě Simeon Polockij ve své poemě «Opeл pocсийскиü» opěvuje. Jejím vytvořením bylo poukázáno na událost veřejného a státního významu - oficiální jmenování a vyhlášení třináctiletého syna cara Alexeje Michajloviče careviče Alexeje následníkem trůnu. Polockij jako autor této velkolepé poemy v ní vyjádřil občanské nadšení, entuziasmus a víru

1 SAZONOVA, L. I.: In: Polockij, Simeon: Orel rossijskij. Moskva: Indrik, 2015, s. 7.

2 Tamtéž, s. 8. 
v tvưrčí sílu ruské mocnosti. Novátorsky je zobrazen dvouhlavý orel jako centrální obraz poemy, který přitom současně symbolizuje jak cara Alexeje Michajloviče, tak celé Rusko.

Další část knihy s názvem «Из историu создания поэмь Орел российский (Z historie vzniku poemy Orel ruský, s. 195-216) pojednává o tom, že donedávna vědci pracovali pouze se dvěma opisy zmiňované poemy, které jsou známy již dávno. Jedním z nich je výše uvedený rukopis z roku 1667, který je uložený v Knihovně Akademie věd v Sankt-Petěrburgu a druhý se jako součást známého sborníku «Рифмологио»» (1678-1680, Rifmologion) nachází ve Státním historickém muzeu v Moskvě. V průběhu zkoumání rukopisného dědictví Simona Polockého se podařilo nečekaně nalézt ještě jeden - třetí opis, který obsahuje autorské opravy, doplňky a vsuvky. A jak ukazují následná textologická zkoumání, tento text posloužil jako originál pro darovaný rukopis, což určuje jeho zvláštní a osobitý význam pro studium dějin vzniku tohoto díla. Nově objevený materiál se nachází ve sborníku РГАДА (RGADA) ve sbírce rukopisů moskevské Synodální tiskárny, č. 389 společně s dalšími díly Simeona Polockého, které jsou napsané v několika jazycích - v latině, polštině, staroběloruštině a v církevní slovanštině.

Následující čtvrtá kapitola $\mathrm{s}$ pojmenováním «Симеон Полочкий - Орел российский. Транслитерированный текст» (Simeon Polockij - Orel ruský. Transliterovaný text, s. 217-294) doprovází faksimilní vydání vysvětlivkami a doplňky tak, aby byl text pro čtenáře srozumitelný a přístupný.

Pátá část má název "Симеон Полочкий.Речъ при вручении книги Орел российский» (Simeon Polockij. Proslov při předávání knihy Orel ruský, s. 295-298) a jak je uvedeno, přináší projev Simona Polockého při př́ležitosti darování knihy carovi Alexeji Michajloviči.

Následuje oddíl «Словаръкомментарий $\kappa$ поэме Орел российский» (Slovník-komentář k poemě Orel ruský, s. 299-326).

Poté jsou přehledně uvedeny "Археографuческие сведения о рукописях, содержаших поэму орел российскиц̆» (Archeografické údaje a in- formace o rukopisech, obsahujích poemu Orel ruský, s. 327-332).

V dalších pasážích publikace jsou úplně poprvé komplexně publikovány a souborně zveřejněny jednotlivé dokumentární přílohy, které jsou - stejně jako poema Orel ruský - věnovány oficiálnímu jmenování careviče Alexeje Alexejeviče následníkem trůnu:

1/ «Чин обълвления наследником престола царевича Алексея Алексеевича. 1 сентлбря 1667 2.» (Vyhlášení careviče Alexeje Alexejeviče následníkem trůnu. 1. záŕí 1667, s. 335-338).

2/ «Обнародование о вступлении в совершеннолетие иаревича Алексея Алексеввича и о бывшей по случаю сему иеремонищ» (Prohlášení o plnoletosti careviče Alexeje Alexejeviče a o slavnostním obřadu k této př́ležitosti, s. 339-347).

3/ «Симеон Полочкий. К великому государю чарю в денъ 1 сентября 1667 г.» (Simeon Polockij: Velkému panovníkovi carovi v den 1. září 1667, s. 348-349).

4/ "Симеон Полочкий. К новолвленному иаревичy» (Simeon Polockij: Nově zrozenému carevičovi, s. 350-351).

5/ «Симеон Полочкий. Диалог краткий о государе иаревиче и великом князе Алексии Алексиевиче» (Simeon Polockij: Krátká rozmluva o carevičovi a velikém knížeti Alexeji Alexejevičovi, s. 352-354).

Závěrečné oddíly v knize obsahují «Сnuсок иллюстраиий» (Seznam ilustrací, s. 357-358), «Список литературь» (Seznam literatury, s. 359366), «Указатель имеџ» (Jmenný rejstřík, s. 367372) a nakonec «Список условных сокращений» (Seznam zkratek, s. 373).

V této souvislosti považujeme za nezbytné připojit ještě několik poznámek, dodatků a drobných postřehů o Simeonovi Polockém - vlastním jménem byl Samuil Jemeljanóvič nebo Samuil Gavrilovič Petrovskij-Sitnianovič (*1629 Polock - †1680 Moskva) - a jeho literární tvorbě. Polockij je považován za prvního profesionálního spisovatele v Rusku, byl jedním ze zakladatelů Slovansko-řecko-latinské akademie - první vysoké školy v Rusku (Славно-греко-латинская академия, 1687), znal perfektně polský a latinský jazyk a byl rovněž řecko-katolickým knězem. 
Vždy smysluplně zdůrazňoval důležitost poetiky a gramatiky. Polockij patří k zakladatelům ruské sylabické poezie a sám také psal básně v podobě uměleckých obrazů, tzv. kaligramů. Ty mají podobu hvězdy, hvězdných paprsků, orla, křiže, čĩše, srdce či tzv. labyrintu - příkladem je báseň s názvem «Царствуй многа лета» (Vládni mnoho let), kterou věnoval carovi Fjodoru Alexejevičovi, kterému byl učitelem a vychovatelem. Blahopřání se v básni objevuje tolikrát, kolik let mu přál. Ve svých výchovných názorech, které vyjádřil v pedagogických spisech «Обед душевныци» (Duchovní oběd, 1681) «Вечеря душевная» (Duchovní večeře, 1683), vycházel a inspiroval se dílem Jana Ámose Komenského. Při tvorbě veršů používal také různé typy akrostichů, kdy písmena nebo slabiky čtené za sebou tvoří slovo nebo větu (alfabetický akrostich, tzv. pravý akrostich, mezostich, telestich, křrižový akrostich, akroteleuton).

Sylabický verš přešel do ruského prostředí z polské literatury a je také typickým pro francouzský jazyk. Simeon Polockij přeložil sylabickým veršem např́klad «Псалтыры» (Žaltář, 1670), později pak knihu pod názvem «Псалтырь рифмотворная» (Žaltář ve verších, 1680), přičemž dodržuje zásadu stejného počtu slabik ve verši - je jich jedenáct (v české poezii se vyskytuje nejčastěji osm slabik - verš osmislabičný, tzv. oktosylab). Polockij nebere v úvahu přízvučné a neprrízvučné slabiky, ale pokaždé klade důraz na to, aby prrízvuk byl na předposlední slabice ve verši.

«Веждъ же и сие, яко псалми сии от древних времен писани святии. Стихов мерою, от муж умудренных, добре елинским книгам изученных.

Тем не дивися, видя ино слово, разум един есть речение ново. Светлости ради ли за нужду меры: толк отверзает всих сокрович двери.»

\section{(Úryvek ze Žaltáře ve veršich, 1680)}

Písmeno neboli literu považuje Polockij za prvopočátek světa a přemýšlí, jak uspořádat tyto prvopočátky. Uvádí, že existuje celý komplex těchto prvopočátků, který je však omezený a ohraničený, ale přesto je současně schopný vyjádřit a postihnout celý svět. A tímto komplexem je slovanská abeceda. Pravdivé - byt zdánlivě paradoxní - je racionalistické tvrzení Simona Polockého, že všechno na světě má mít své pojmenování, a i když je svět nekonečný, všechno se vejde do jedné jediné abecedy. Svět si představuje jako knihu a jednotlivé části světa jsou v přeneseném významu části knihy - listy, stránky, řádky, slova, písmena.

«Мир сей преукрашенный - книга есть велика, еже словом написа всяческих владыка.

Пять листов препространных в ней ся обретают, яже чюдна писмена в себе заключают.»³

Simeon Polockij je autorem komediálního školního dramatu s názvem «Притча о блудном сыне» (Podobenství o marnotratném synovi, 1680), jehož námětem je tradiční konflikt „otců a dětí".

Sestavil také dva literární sborníky - «Bepmoградмногочветный» (Zahrada mnohokvětá, 1678) a «Рифмологион» (Rifmologion, 1680), v nichž projevuje své osvětářské úsilí a prostřednictvím různých podobenství a příběhů na historické motivy seznamuje čtenáře s antikou i se západní literaturou. Obrazně řečeno - Polockij přesazuje květiny z jedné zahrady do druhé. Podle slov ruského literárního vědce I. P. Jeremina (1904-1963) «стихотворения Вертограда производят впечатление своеобразного музея, на витринах которого расставлены вещи, часто редкие и очень древние. Тут выставлено для обозрения все основное, что успел Симеон, библиофил и начетчик, любитель разных раритетов и куриезов, собрать в течение своей жизни у себя в памяти. ${ }^{4}$

Svým životem i tvorbou razil a prosazoval Simeon Polockij cestu typicky ruského osvícenství a podobně jako jeden z jeho nejbližších žáků Silvestr Medveděv formoval, proslavoval a šíril

3 LICHAČEV, D. S.: Istorija russkoj literatury X-XVII vekov. Moskva: Prosveščenije, 1980, s. 439.

4 JEREMIN, I. P.: Poetičeskij stil Simeona Polockogo. TODRL, 1948 , t. 6. , s. 125. 
slovanský jazyk a ruský stát. Je potvrzeno a his- kům v oboru staré ruské a klasické literatury, toricky dokumentováno, že toto jeho snažení literární vědy a komparatistiky, nýbrž také dalpodporoval i samotný car Petr I. Veliký. ším badatelům, pedagogům a vědcům, kteří

Závěrem konstatujeme, že posuzovaná originální publikace je nepochybně značným přínosem pro kompletizaci dějin ruské literatury a pro zpř́stupnění vzácných ruských písemných památek. Je určena nejen všem odborníchtějí zevrubněji a precizněji porozumět širším souvislostem nastolené mnohotvárné a barvité literární tematiky, která je neodmyslitelnou a trvalou součástí veškerého slovanského písemnictví.

\section{doc. PaedDr. Zdeňka Matyušová, Ph.D.}

Katedra slovanských jazyků a literatur

Pedagogická fakulta, Jihočeská univerzita

Jeronýmova 10, 37115 České Budějovice, Česká republika

matyus@pf.jcu.cz 